\title{
(Re)defining the English Reformation
}

\author{
Peter Marshall
}

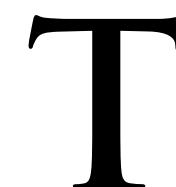

he study of the Reformation has arguably never been in better shape, as new books and articles appear with dizzying regularity. The current rude good health of the subject can be substantiated by a few minutes spent with the catalog of the British Library. A title keyword search under "Reformation" produces 490 items for the 1960s, dipping to 449 for the 1970s. But in the 1980s, this shoots up to 656 and remains at almost exactly that level through the 1990s. In the new century up to the end of 2007 , no fewer than 563 books with the word "Reformation" in the title have been published and deposited at the British Library. Moreover, the concerns of Reformation history and theology are now regularly cropping up in places where they have not been much in evidence before: in art history, musicology, and literary studies, for example. To point to just one particular case, the study of William Shakespeare-always a reliable barometer of Anglo-American cultural and academic preoccupations-has taken a decidedly religious turn over recent years, in which questions of the meaning and impact of the Reformation are very much to the fore. ${ }^{1}$ The collective problem faced by students of the Reformation, if indeed we have a problem, is not therefore one of nurturing a tender and precarious plant, struggling to thrive in stony and unyielding historical soil. Rather, it is the challenge of maintaining order and coherence in a large and untidy garden, alive with luxuriant foliage, periodic colorful blooms, and a smattering of undesirable weeds.

My own corner of the meadow-the Reformation in England-has certainly

Peter Marshall is professor of history at the University of Warwick. An earlier version of this article was delivered as a plenary lecture at the Society for Reformation Studies Conference on (Re)defining Reformation, Westminster College, University of Cambridge, in March 2008. The author is grateful to participants on that occasion - especially David Bagchi, Euan Cameron, and Ian Hazlett-for insightful comments. He is also indebted to Eric Carlson, Norman Jones, Alec Ryrie, and John Watkins for helpful suggestions.

${ }^{1}$ See, among other works, Stephen Greenblatt, Hamlet in Purgatory (Princeton, NJ, 2001), Will in the World: How Shakespeare Became Shakespeare (New York, 2003); Richard Dutton, Alison Findlay, and Richard Wilson, eds., Theatre and Religion: Lancastrian Shakespeare (Manchester, 2003); Richard Wilson, Secret Shakespeare: Studies in Theatre, Religion and Resistance (Manchester, 2004). See also Ken Jackson and Arthur F. Marotti, "The Turn to Religion in Early Modern English Studies," Criticism 46, no. 1 (Winter 2004): 167-90.

Journal of British Studies 48 (July 2009): 564-586

(C) 2009 by The North American Conference on British Studies.

All rights reserved. 0021-9371/2009/4803-0007\$10.00

564 
not been short of would-be gardeners, and even ambitious landscape designers, over the past two to three decades. The once-accepted narrative of the English Reformation has been refined, redefined, and rewritten to the extent that it is hardly recognizable as the same story. A revisionist surge in English Reformation scholarship, which gathered pace through the 1980s and reached its apogee in the work of Eamon Duffy in the 1990s, swept away the old certainties, as surely as the reformers swept away the altars, images, and shrines from the churches of mid-Tudor England. ${ }^{2}$ In its wake, a number of formerly conventional ideas about the English Reformation have come to seem simply untenable. ${ }^{3}$ Historians formerly believed that the Reformation came about in Henry VIII's reign through a constructive alliance between the Crown and an anticlerical laity, disillusioned by the institutional corruption and spiritual malaise of the late medieval Church. They also usually assumed that Protestant precepts of sola fide and sola scriptura rapidly and extensively captured the imaginations of the English people in the mid-sixteenth-century decades; as the leading Tudor specialist of the day, G. R. Elton, announced in 1977, the reign of Edward VI brought about "a real transformation among the people" and "by 1553 England was almost certainly nearer to being a Protestant country than to anything else." 4 The short reign of Catholic Mary Tudor was an unfortunate blip, and the accession of Elizabeth in 1558, and her promulgation of a moderate Protestant settlement the following year, brought the Reformation to a fitting and triumphant conclusion.

The revisionist scholarship of Duffy, Jack Scarisbrick, and Christopher Haigh systematically dismantled this progressivist narrative. ${ }^{5}$ Self-consciously liberating itself from inherited Protestant and nationalistic assumptions and making much use of parish-based sources such as churchwardens' accounts, revisionism argued that the Reformation was neither swift nor inevitable. These scholars made the case for late medieval Catholicism as a flexible and dynamic religious system and for much resistance and reluctance at the popular level to the implementation of reform. In consequence, most scholars now accept that the Reformation in England was a thorny and protracted process and by no means straightforwardly unidirectional.

Yet revisionism has raised questions of its own, and the study of the Reformation has now discernibly passed into a postrevisionist phase. "Postrevisionism" is an elusive and catch-all term. As it has been applied to historians of the English Reformation, it usually implies a readiness to regard the phenomenon as a gradual yet profound cultural transformation rather than as the swift Protestant victory of traditional historiography or as the long-drawn-out and remarkably successful Catholic rearguard action portrayed by 1980s revisionism. Nonetheless, I think it is fair to say that most postrevisionism is not so much a blanket refutation of revisionism as an acceptance of the need to work outward from some of its basic

\footnotetext{
${ }^{2}$ Eamon Duffy's The Stripping of the Altars: Traditional Religion in England, 1400-1580 (New Haven, CT, 1992) built on the insights of J. J. Scarisbrick, The Reformation and the English People (Oxford, 1984).

${ }^{3}$ The following sentences represent an (only slighted simplified) summary of the main theses of A. G. Dickens, The English Reformation (London, 1964), a book widely hailed upon its first publication as a definitive and unimpeachable study.

${ }^{4}$ G. R. Elton, Reform and Reformation: England, 1508-1558 (London, 1977), 371.

5 "Revisionism" became firmly established as the appropriate term of art with the publication of a volume of essays edited by Christopher Haigh: The English Reformation Revised (Cambridge, 1987).
} 
premises, such as the fundamental vitality of late medieval parochial and popular religion and the distinctly limited appeal exerted by Protestant ideas in the first decades of their introduction. ${ }^{6}$ Indeed, the two leading revisionist scholars of the current generation, Christopher Haigh and Eamon Duffy, have both in the last few years indicated a willingness to sport the postrevisionist badge themselves. ${ }^{7}$

Meanwhile, the straightforward concept of an English Reformation-The English Reformation, as emblazoned in the title of A. G. Dickens's magisterial book of 1964-has been poked, prodded, reconfigured, and reassessed to the extent that it has become legitimate to question whether there was meaningfully such a thing as the English Reformation at all. Some scholars are now arguing, implicitly or explicitly, that the religious affairs of England are understandable only as part of the pattern of a wider British Reformation-of the interconnections between people, ideas, and state policy in all the constituent parts of what we are sometimes urged to call "the Atlantic Archipelago." Ian Hazlett has a stern monition for those of us who have largely confined ourselves to the study of religious change in England: "They who only know the Reformations in England, Scotland, Ireland or Wales do not really know the Reformations in England, Scotland, Ireland or Wales." I am going to leave the British question aside for the moment, in order to note that there have been other scholars still more radically deconstructive of the whole concept of an English Reformation. None has proved more so than the Oxford historian Christopher Haigh, who pointedly gave the title English Reformations to his general survey of 1993, dispensing both with the reassuringly familiar singular and with the reserve parachute of a definite article. The essential point he wanted to make was that there was nothing that took place in the sixteenth century that was in any way qualitatively different from the abortive Puritan Reformation of the mid-seventeenth century or the Methodist and evangelical campaigns of the later eighteenth. Haigh's reformations are "haphazard and limited," "discontinuous . . . and parallel," driven forward, back, and sideways by the contingencies of politics and foreign policy. It is, in his view, a serious fallacy to bundle all the events of the sixteenth century into one "big event" and to invoke for it any grand underlying causes. To do so is to reveal oneself as a neo-Whig and a teleologist. ${ }^{10}$

Haigh's perception has, up to a point, been endorsed by other historians. His

\footnotetext{
${ }^{6}$ Explicitly recognized, for example, by one of the most influential postrevisionist studies, Ethan Shagan, Popular Politics and the English Reformation (Cambridge, 2003), 5, suggesting that in a straight contest between the interpretation of Dickens and that of Duffy and Haigh, the latter "win hands down."

${ }^{7}$ Haigh makes the suggestions that "we are (almost) all post-revisionists now" in a review of Alexandra Walsham's Providence in Early Modern England in the English Historical Review 115, no. 463 (September 2000): 964-65. Duffy claims the postrevisionist label for his The Voices of Morebath: Reformation and Rebellion in an English Village (New Haven, CT, 2001) in a survey essay, "The English Reformation after Revisionism," Renaissance Quarterly 59, no. 3 (September 2006): 724.

${ }^{8}$ See Felicity Heal, Reformation in Britain and Ireland (Oxford, 2003); Ian Hazlett, The Reformation in Britain and Ireland (Edinburgh, 2003); and a forthcoming study by Alec Ryrie. The archipelagic paradigm more broadly was advocated by J. G. A. Pocock, "The Limits and Divisions of British History: In Search of the Unknown Subject," American Historical Review 87, no. 2 (April 1982): 311-36. See also Brendan Bradshaw and John Morrill, eds., The British Problem, c.1534-1707: State Formation in the Atlantic Archipelago (Basingstoke, 1996).

${ }^{9}$ Hazlett, The Reformation in Britain and Ireland, xiii-xiv.

${ }^{10}$ Christopher Haigh, English Reformations: Religion, Politics, and Society under the Tudors (Oxford, 1993), 12-15.
} 
Oxford colleague Diarmaid MacCulloch has written recently that in England there were "as many Reformations as there were monarchs on the Tudor throne after the break with Rome," although he adds the crucial rider that there were also other reformations, "the reformations of ordinary people, scholars, clergy, all of which might clash with what the English monarchs were doing as much as they might support the religious changes imposed from above." ${ }^{11}$ The growing acceptance of the utility of a notion of plural reformations, either within or lying outside a larger conceptual frame, has had very significant consequences for chronology and periodization, for not all of these reformations were working on anything like the same timescale. "The Reformation" was once widely regarded as a historical event, initiated in Henry VIII's reign and essentially concluded within the space of three decades. But only a political and statutory Reformation can be considered in any way complete by the early part of Elizabeth I's reign, and then only with the benefit of hindsight. An important clarion call on this point was sounded by Patrick Collinson, the doyen of historians of early modern English Protestantism. In a set of lectures of 1986, subsequently published as The Birthpangs of Protestant England, Collinson declared himself ready to assert "crudely and flatly, that the Reformation was something which happened in the reigns of Elizabeth and James I. Before that everything was preparative, embryonic." 12 Nearly a quarter of a century on, that assertion looks more like an opening negotiating position than a concluding statement, for the Reformation has in the years since become increasingly stretched and malleable. A crucial milestone here was the Neale Colloquium held at University College London in January 1996 on the theme of the "Long Reformation." The volume generated by the conference suggested that, in some eyes, England's Long Reformation had become very long indeed, including as it did chapters on Bristol in the later seventeenth and eighteenth centuries and on the evangelistic strategies of the Methodist movement. Not all the contributors felt constrained by the subtitular dates of 1500-1800, with at least one seeing an identifiably Reformation process still under way in the early Victorian period. ${ }^{13}$ At around the same time, another noteworthy collection of essays (a Festschrift for the Reformation historian Paul Seaver) similarly spread itself well into the eighteenth century. ${ }^{14}$

Deciding just when it was that the English Reformation came to an end has become an enjoyable parlor game among historians. One solution is to think of it in terms of life cycles and generational change, an approach that has been

\footnotetext{
${ }^{11}$ Diarmaid MacCulloch, "The Church of England, 1533-1603," in Anglicanism and the Western Christian Tradition, ed. Stephen Platten (Norwich, 2003), 18.

${ }^{12}$ Patrick Collinson, The Birthpangs of Protestant England: Religious and Cultural Change in the Sixteenth and Seventeenth Centuries (Basingstoke, 1988), ix. While extending the chronology of the Reformation (in order to emphasize the slow progress of reform) has from the outset been part of the revisionist project, in the hands of Collinson and others it has paradoxically also served to make the anti- or postrevisionist point that Protestantism was ultimately influential and transformative. See also MacCulloch's contention that by the very end of the sixteenth century the Reformation should be considered a "howling success" ("The Impact of the English Reformation," Historical Journal 38, no. 1 [March 1995]: 152).

${ }^{13}$ See Nicholas Tyacke, ed., England's Long Reformation, 1500-1800 (London, 1998), especially the chapters by Jonathan Barry, W. R. Ward, and Jeremy Gregory.

${ }^{14}$ Muriel C. McClendon, Joseph P. Ward, and Michael MacDonald, eds., Protestant Identities: Religion, Society, and Self-Fashioning in Post-Reformation England (Stanford, CA, 1999).
} 
fruitfully pioneered by Norman Jones and takes us just into the early Stuart era. ${ }^{15}$ There is a case to be made for looking farther forward to 1660, to the restoration of the monarchy and Church of England, and with it the collapse of godly hopes for thoroughgoing reformation of society. A slightly longer perspective would take us to the revolution of 1688 , the moment when it was definitively decided that the supreme governor of the Church of England needed to be a Protestant. Or perhaps, still better, to 1689 , when toleration was enacted into law and the Church lost officially and forever its aspiration to maintain a monopoly on religious worship and allegiance. My own cards were laid on the table when I published a textbook in 2003 that terminated the story with the outbreak of civil war in England in 1642. ${ }^{16}$ By titling the book Reformation England - a broad chronological coverlet rather than a solidly essentializing bedpost - some critics might, however, suspect me to be sleeping through a crucial point at issue. Nonetheless, among cultural historians of the English Reformation at least, a workaday consensus seems to be emerging that circa 1640 is a useful moment at which to pause and take stock. ${ }^{17}$

There have been evident benefits of the chronological extension of the English Reformation. For one thing, a strict and artificial division of labor between historians studying the outcomes of sixteenth-century religious change and those looking into the origins of the civil and religious strife of the mid-seventeenth century has been pretty thoroughly eroded. This indeed was a process that was already observable over twenty years ago, when Nicholas Tyacke and Patrick Collinson, looking through opposite ends of the telescope, simultaneously and independently discovered something that can be called a "Calvinist consensus" operating in the Elizabethan and Jacobean Church. They argued that, in spite of occasional spats between bishops and their Puritan critics, adherence to Calvin's doctrine of predestination was virtually universal among English Protestants, providing a "common and ameliorating bond" between prelates, clergy, and educated laity. It was only when court-favored preachers began questioning that doctrine in the reign of Charles I that religious tensions rose to the point where civil war became a possibility. ${ }^{18}$

Yet at the same time there are obvious problems in studying and explaining the English Reformation in any of its long, longer, and longest variants. As it gets bigger, it becomes more difficult for any one historian to retain a comprehensive command of the battlefield. There is a tendency for scholarly forces to splinter and end up involved in a series of intensely localized historiographical skirmishes and guerrilla campaigns around particular events or subperiods. Concern is also being expressed in some quarters about the implications of the Reformation becoming thematically and chronologically a larger topic, with increasingly sophisticated postrevisionist

\footnotetext{
${ }^{15}$ Norman Jones, The English Reformation: Religion and Cultural Adaptation (Oxford, 2002).

${ }^{16}$ Peter Marshall, Reformation England, 1480-1642 (London, 2003).

${ }^{17}$ For example, Tessa Watt, Cheap Print and Popular Piety, 1550-1640 (Cambridge, 1991); Eric Carlson, ed., Religion and the English People, 1500-1640 (Kirksville, MO, 1998); Alexandra Walsham, Providence in Early Modern England (Oxford, 1999); Peter Marshall, Beliefs and the Dead in Reformation England (Oxford, 2002).

${ }^{18}$ Patrick Collinson, The Religion of Protestants: The Church in English Society, 1559-1625 (Oxford, 1982); Nicholas Tyacke, Anti-Calvinists: The Rise of English Arminianism, c.1590-1640 (Oxford, 1987). Tyacke's thesis was first advanced in his essay "Puritanism, Arminianism and Counter-Revolution," in The Origins of the English Civil War, ed. Conrad Russell (London, 1973), quote at 121.
} 
scholarship drawing attention to its nuances and paradoxes, its long-term continuities and discontinuities, and its intended and unintended consequences. Such a Reformation may become a harder topic to teach to students or with which to engage the interest of a wider reading public. ${ }^{19}$ There is very considerable appeal in a simple, comprehensible, and stirring narrative-whether it is one of Protestant achievement or a counternarrative of Catholic refusal and resistance.

What, then, is the sensible way forward? Is it time for English Reformation historians to follow the lead of the distinguished Jesuit scholar, John O'Malley, who has made a powerful case for abandoning the freighted terms "CounterReformation" and "Catholic Reformation" in favor of viewing the interrelated developments in European religion, politics, and culture in the sixteenth and seventeenth centuries through the more neutral and objective lens of "early modern Catholicism"? ${ }^{20}$ Why should we not just study "early modern English Christianity" without fetishizing the origins, course, and consequences of something called "the English Reformation"? Or perhaps we should simply and cheerfully break up into our own subspecialisms-parcel out what was once thought of as the common land of the English Reformation into individual scholarly allotments and not worry too much about it.

It would, I think, be a shame to follow these paths, for a couple of weighty reasons. In the first place, contested labels and problematic periodizations are often much better at focusing debate, promoting research, and advancing understanding than are neutral and uncontroversial ones. And second, "the Reformation" is of course not just an artificial construct of later historians but a central perception and organizing category of contemporaries themselves. A few short quotations from Protestant writers of the Elizabethan and Jacobean periods will serve to underline this obvious point. From the perspective of 1610, John Donne looked back across a period "since the Reformation of the Church was courageously begun, and prosperously and blessedly prosecuted." ${ }^{21}$ The moderate Puritan Andrew Willet rejoiced that his own age had seen "the sects of Friers in many places put downe: the Popish iurisdiction cast out; a notable reformation to be wrought in the Church." 22 Bishop Lancelot Andrewes was no less eager to hail "the Reformation of the Church of England, and the ejection of Popery." ${ }^{23}$ The martyrologist John Foxe headed a section in his Acts and Monuments, "Here beginneth the reformation of the church of Christ, in the tyme of Martin Luther." ${ }^{24}$ But Luther was not invariably credited as the sole and prime mover. The Jacobean

\footnotetext{
${ }^{19}$ Remarks to this effect were made by Patrick Collinson in the closing plenary address to a conference on "Sites of Change in Reformation England," held at the University of Warwick in February 2008. See also Haigh's review of my Reformation England, in The English Historical Review 121, no. 491 (April 2006): 604-5.

${ }^{20}$ John W. O'Malley, Trent and All That: Renaming Catholicism in the Early Modern Era (Cambridge, MA, 2000).

${ }^{21}$ John Donne, Pseudo-martyr Wherein out of certaine propositions and gradations, this conclusion is enicted: That those which are of the Romane religion in this kingdome, may and ought to take the Oath of allegiance (London, 1610), 251.

${ }^{22}$ Andrew Willet, Synopsis papismi, that is, A generall viewe of papistry (London, 1592), 68.

${ }^{23}$ Lancelot Andrewes, Of episcopacy three epistles of Peter Moulin . . . answered by . . . Lancelot Andrews (London, 1647), 29.

${ }^{24}$ John Foxe, Acts and Monuments . . . (1576), 803 [online], http://www.hrionline.shef.ac.uk/ johnfoxe.
} 
anti-Catholic polemicist Matthew Sutcliffe, for example, did not hesitate to identify the late medieval heresiarchs John Wyclif and Jan Hus among those who "haue laboured in the reformation of the Church." 25

There are some significant points to note here. Early seventeenth-century Protestant writers did not generally view the Reformation as a past historical event. Instead, the phrase "the reformation of the church" was usually employed to designate a work in progress. It is, in a sense, rather reassuring to find contemporaries prefiguring two of the central insights of recent historical writing: that the English Reformation was a long Reformation and that it was a process, not an event. But their views of the matter were hardly identical to those of modern scholarship - not least because the ongoing Reformation of the Church was often placed squarely in an apocalyptic framework. The Calvinist author George Downame, in a preface celebrating the accession of James I to the English throne, remarked that to him the event "seemeth to presage, that the happy reformation of the church, restitution of the Gospell, consumption of Antichrist, decay of Babilon happily begun in the last centenary, shall in this age or century receiue a notable confirmation and increase." 26 James's archbishop of Canterbury, George Abbot, placed the "reformation in these later Ages" in a millenarian historical sequence spanning the degeneration of the Church after the year 666 and the unloosing of Antichrist in the year 1000. ${ }^{27}$

We have to remember, in other words, that from its inception, the concept of the Reformation was not a neutral term of observation but an ideological construct, a point underlined by the reference in numerous Catholic polemical works to the "pretended Reformation" of the Protestants. ${ }^{28}$ If we decide to retain the English Reformation as our principal category of analysis-as I think we should-we need to bear this charged and freighted character of the concept in mind. It also behooves us to ensure that we do not end up unconsciously replicating any of the particularist agendas of our own historical subjects.

In the following part of this essay, and with these caveats in mind, I want to address some of the other methodological and conceptual problems besetting the study of the English Reformation at the present time. I will then go on to offer, if not exactly a set of prescriptions, at least some gestures toward the directions that some of the best Reformation research is currently taking and that future research on the topic might fruitfully take.

The first of these problems is one that I am not sure I actually recognize as a difficulty. But it is now being aired and raised to the extent that it has become virtually impossible to avoid talking about it altogether. The question is that of whether the academic study of the English Reformation is bedeviled by the retention, or even the revival, of confessional perspectives and allegiances among

\footnotetext{
${ }^{25}$ Matthew Sutcliffe, The subuersion of Robert Parsons his confused and worthlesse worke, entituled: $A$ treatise of three conuersions (London, 1606), 92.

${ }^{26}$ George Downame, A treatise concerning Antichrist divided into two bookes (London, 1603), A2r.

${ }^{27}$ George Abbot, A treatise of the perpetuall visibilitie, and succession of the true church in all ages (London, 1624), A3r.

${ }^{28}$ For example, Thomas Fitzherbert, An adioynder to the supplement of Father Robert Persons his discussion of M. Doctor Barlowes answere (Saint-Omer, 1613), 449; Richard Verstegan, Newes from the low-countreyes (Saint-Omer, 1622), 21; John Fisher, The answere vnto the nine points of controuersy, proposed by our late soueraygne (Saint-Omer, 1626), 230.
} 
historians themselves. Some leading voices clearly believe this to be the case. At a conference at the University of Warwick in 2008, Patrick Collinson identified "the return of confessionalism" as one of the key and worrying traits in current English Reformation research..$^{29}$ Another front-rank Reformation scholar has gone further. In a recent essay, MacCulloch states unambiguously that "I commend the advantages of emancipating religious history from specific religious commitment." While conceding that good scholarship has been and continues to be produced by historians with affiliations to a branch of Christian faith, MacCulloch worries about the problem of "ancestor worship," the tendency to focus attention on the perceived progenitors of one's own denomination. As a result, religious figures and movements without modern descendants tend to become lost or marginalized, and crucial "silences" in the historical record of Reformation patterns can easily be overlooked-MacCulloch has in mind here groups like the shadowy sect the Family of Love, or "Nicodemites" (merely outward conformists) of all descriptions. As an exemplar of critical distance, MacCulloch holds up for us the historian of comparative Calvinism, Philip Benedict, who has proudly proclaimed his origins as "a total outsider, an agnostic, nonpracticing Jew raised in a secular household." In the foreword to his massive 2003 history of the European Reformations, MacCulloch was equally frank, claiming that "historical narratives told with a confessional viewpoint lurking in the background are very likely to bend the story to fit irrelevant preconceptions." ${ }^{31}$

In the past few years, "postconfessionalism" has become a buzzword, perhaps even a slogan, in Reformation history circles, the theme of a plenary roundtable at the 2004 meeting of the Sixteenth Century Studies Society and of a follow-up focal group discussion, or Themenschwerpunkt, in a 2006 issue of the Archiv für Reformationsgeschichte. ${ }^{32}$ Some books in the field, such as a 2005 collection on English Catholics, now explicitly bill themselves as postconfessional histories. ${ }^{33}$ Postconfessionalism in this context is undoubtedly intended to describe not just a historical moment at which we have all collectively arrived but a chosen attitude of mind and method. The nervousness in some quarters about being associated with any hint of theistic belief has become quite far-reaching. Thus, the series editor's standing preface to a recently established monograph series on early modern Catholic history is eager to insist that "the goal is to understand religion . . . as a broadly human phenomenon, rather than as a privileged mode of access to superhuman realms, even implicitly." 34

There is, I think, little doubt about where much of this apparent nervousness in the academy has come from. The extraordinary success and influence of Eamon

\footnotetext{
${ }^{29}$ Collinson, "Sites of Change."

${ }^{30}$ Diarmaid MacCulloch, "Protestantism in Mainland Europe: New Directions," Renaissance Quarterly 59, no. 3 (September 2006): 704-6.

${ }^{31}$ Diarmaid MacCulloch, Reformation: Europe's House Divided, 1490-1700 (London, 2003), xxv.

32 "Focal Point: Post-confessional Reformation History," Archiv für Reformationsgeschichte 97 (2006): 276-306. The contributors, who offer a variety of perspectives on the issue, are Susan KarantNunn, Anne Jacobson Schutte, Philip Benedict, Scott Hendrix, Lyndal Roper, and Ethan Shagan.

${ }^{33}$ Ethan Shagan, "Introduction: English Catholic History in Context," in his Catholics and the "Protestant Nation" (Manchester, 2005), 1.

${ }^{34}$ Thomas F. Mayer, "Series Editor's Preface," in all volumes of Catholic Christendom, 1300-1700 (Ashgate, 2004-).
} 
Duffy's The Stripping of the Altars in the field of English Reformation studies has from the outset been coupled with widespread awareness of, and comment on, the circumstance that its author is a deeply committed Roman Catholic layman. This, coupled with the fact that a significant historiographical precursor to Duffy, Scarisbrick's The Reformation and the English People, was also authored by a politically prominent British Catholic, has encouraged some critics to identify a confessionally grounded school of historical interpretation at work: Catholic revisionism. This is a phenomenon perhaps more substantial in the eye of some beholders than in reality, for it would appear that not all Catholic revisionists are actually Roman Catholics. The fact that Christopher Haigh, a self-styled Anglican agnostic, is regularly accused of belonging to this tendency has for some time been a source of wry amusement to himself and to others. More incongruously still, a new biography of Luther identifies the late Richard Marius, along with Haigh, as another of the Catholic apologists of whom readers ought to be wary. Marius was in fact a religious skeptic and a sometime Southern Baptist. ${ }^{35}$

Duffy himself has now explicitly addressed the issue in print, and it is fair to say that he has not entirely sought to douse the fire that some clearly suspect to be smoldering beneath the smoke of so-called Catholic revisionism. He freely acknowledges that there is a "notable Catholic presence" in Reformation-related studies, naming John Bossy, Peter Burke, and Bob Scribner in this connection, as well as, in the younger generation, myself and Richard Rex. In part, Duffy adduces a sociodemographic explanation for this phenomenon: the greater numbers of Catholics entering higher education in Britain in the years after the 1944 Education Act. But he also detects a kind of elective affinity between Catholic academics, practicing or lapsed, and the study of late medieval and early modern religion, a greater openness on the part of those formed in the Catholic tradition to the internal logic and symbolic coherence of a generally alien cultural world. Insofar as Catholic revisionism exists at all, suggests Duffy, it may simply represent "the absence of a Protestant historiographical agenda at least as much as the presence of a Catholic one." Not unreasonably, Duffy points to the fact that critics have seldom or never commented on the Protestant faith, or the Protestant cultural background, of very significant numbers of historians of the English Reformation over many decades. ${ }^{36}$

Yet this too has started to change, and sensitivity to the issue of confessional perspective in English Reformation studies is no longer simply a game of "spot the Catholic." In a recent historiographical essay, the young (and Anglican) historian Alec Ryrie is quite prepared to name and shame, or at least to name, right across the ecclesiastical spectrum. So he writes about the "Protestant historian" Patrick Collinson and draws attention to a "confessionally colored" Anglican view of Reformation developments, exemplified by the writings of an Oxford-based scholar who is also a priest of the Church of England, Judith Maltby. ${ }^{37}$ The idea

\footnotetext{
${ }^{35}$ Haigh, English Reformations, vii; Duffy, "English Reformation after Revisionism," 723; David Daniell, William Tyndale: A Biography (New Haven, CT, 1994), 95, 398n; Derek Wilson, Out of the Storm: The Life and Legacy of Martin Luther (London, 2007), xi. See also http://en.wikipedia.org/ wiki/Richard_Marius.

${ }^{36}$ Duffy, "English Reformation after Revisionism," 722-23.

${ }^{37}$ Alec Ryrie, "Britain and Ireland," in his Palgrave Advances in the European Reformations (Basingstoke, 2006), 125-26.
} 
that an identifiably "Anglican agenda" can be detected in much recent Reformation scholarship has been taken further by a leading historian of Puritanism, Peter Lake, who warns that "many modern historians of the period retain a stake—rarely owned or explicated-in the very disputes they are seeking to explain." ${ }^{38}$ In a succession of books and articles, Lake, sometimes writing in collaboration with Michael Questier, has accused an entire cohort of leading Reformation historians-Maltby, Alexandra Walsham, Norman Jones, Ian Green, Christopher Marsh-of manufacturing an overly consensual Anglican religious culture for the immediate postReformation period, and of doing so largely by choosing to take at something close to face value highly polemical constructions of both Puritanism and Laudianism, positions from which the majority of the people can be presented as sensibly dissenting. ${ }^{39}$

It is possible, I think, to remain fairly sanguine in the face of this brouhaha. The whole debate about whether people with religious convictions can be trusted with religious history is not a new one, although its current iteration may conceivably be a distant echo of wider concerns about religion in the public sphere in the aftermath of $9 / 11$ and seems destined to produce more heat than light. How could we establish meaningful criteria to demonstrate that nontheists write better religious history than theists or, indeed, vice versa? It is perhaps true that believers have to guard against the seductive illusion of sameness, of conflating the priorities of early modern religious systems with those of their evolutionary descendents in the modern world. ${ }^{40}$ But at the same time they can bring to their subject rich reserves of empathy and an innate suspicion of crassly functionalist models of religious belief, commitment, and motivation. It is tempting for them to retort that those who have never had a "religious experience" may be less sensitized to the cultural meanings of the sources generated by such experiences and liable to miss some of the very things that made religion work for early modern people. ${ }^{41}$ It is also worth noting here en passant that MacCulloch's two test cases, Nicodemism and Familism, have hardly lacked for effective and sympathetic studies in recent years and that these studies have not been written from any noticeably agnostic or nontheistical standpoint. ${ }^{42}$

\footnotetext{
${ }^{38}$ Peter Lake, "Anti-Puritanism: The Structure of a Prejudice," in Religious Politics in Post-Reformation England, ed. Kenneth Fincham and Peter Lake (Woodbridge, 2006), 86.

${ }^{39}$ Ibid.; Peter Lake, "Puritanism, Arminianism and Nicholas Tyacke," in Fincham and Lake, Religious Politics in Post-Reformation England, 13; Peter Lake and Michael Questier, The Antichrist's Lewd Hat: Protestants, Papists and Players in Post-Reformation England (New Haven, CT, 2002), 316-19, "Introduction," in their Conformity and Orthodoxy in the English Church, c.1560-1660 (Woodbridge, 2000), i-xx, and "Margaret Clitherow, Catholic Nonconformity, Martyrology and the Politics of Religious Change in Elizabethan England," Past and Present, no. 185 (November 2004): 43-90, at 87.

${ }^{40}$ A point made effectively by the (believing) historian Patrick Collinson, "Religion, Society, and the Historian," Journal of Religious History 23, no. 2 (June 1999): 150-51.

${ }^{41}$ For a powerfully polemic argument against reductionist approaches to early modern religion, see Brad Gregory, Salvation at Stake: Christian Martyrdom in Early Modern Europe (Cambridge, MA, 1999), 342-52. See also the subtle reflections of James D. Tracy, "Believers, Non-believers, and the Historian's Unspoken Assumptions," Catholic Historical Review 86, no. 3 (July 2000): 403-19.

${ }^{42}$ Alexandra Walsham, Church Papists: Catholicism, Conformity and Confessional Polemic in Early Modern England (Woodbridge, 1993); Christopher W. Marsh, The Family of Love in English Society, 1550-1630 (Cambridge, 1994); Andrew Pettegree, "Nicodemism and the English Reformation," in his Marian Protestantism: Six Studies (Aldershot, 1996), 86-117. As an example of how believing historians can write empathetically and insightfully about traditions other than their own, see the study
} 
The charge that believers are incapable of historical objectivity about the Reformation-because they have a personal and ideological investment in the issues at stake-is in any case an oddly selective one. Academic historians, like everybody else, are the individual products of historically rooted cultural and political processes, carried to their present-day intellectual havens on one or more of the ideological currents of the past. Some of the discourse generated by these issues seems predicated on the distinctly dubious assumption that only the religiously inclined have allegiances, preoccupations, or prejudices and that a stance of nonbelief is an objective, impartial standard from which scholars who ought to know better somehow egregiously depart. ${ }^{43}$ Nonbelievers, secularists, and liberal heirs of the Enlightenment very rarely have their credentials publicly checked or feel any need to let their colors openly show. ${ }^{44}$ It is hardly a surrender to the wilder impulses of postmodernism to admit that what draws scholars to the study of the Reformation is often a personal engagement or debate with religion or at least a set of convictions about religion's meaning, importance, and potential in the world. And that is something on which everyone-whether they will admit it or nothas a view.

Modern political culture, in the United States and in Great Britain, is periodically accused of focusing on personalities not policies. It is tempting to wonder whether this concern with the philosophical standpoint of the practitioners of English Reformation history might not in some way be symptomatic of a deeper malaise within the subject itself. The English Reformation has, of course, had many historiographical debates, but beyond rewriting the chronology, these debates have not proved especially adept at developing and employing new conceptual tools in order to define, or redefine, the shape of the subject as a whole. Perhaps we are confronting here an Anglo-American (but particularly British) tradition of solidly empirical research, a suspicion of theoretical modeling and of overarching grand narratives, characteristics that have been the lifeblood of several variants of revisionism. Collectively, we historians of the English Reformation have found it difficult to move very much beyond the seductively straightforward set of paradigms that Christopher Haigh produced for us in a seminal article of 1982: the option to decide whether the Reformation process was fast or slow, and implemented from above or below. ${ }^{45}$ Postrevisionism has certainly complicated the picture, but, it can be argued, only by adding a further binary variable - full-blooded or partialto the interpretative grid. There have of course been some self-conscious attempts to import new conceptual and theoretical models into the understanding of re-

of the Calvinist and Puritan Richard Greenham by Kenneth Parker and Eric Carlson (a Roman Catholic and an Episcopalian): "Practical Divinity": The Works and Life of Revd Richard Greenham (Aldershot, 1998).

${ }^{43}$ Among contributors to the Archiv für Reformationsgeschichte "Focal Point," Lyndal Roper is unusually discerning in this respect, remarking that she regards, for example, socialist and feminist history as types of "confessional history" ("Allegiance and Reformation History," 294).

${ }^{44}$ Peter Lake is an almost unique exception in this regard. An illuminating footnote in a 2006 essay reads: "In calling for others to let their assumptions show rather more explicitly, I should add that I am an adherent of the ideology known, in certain circles in the US, as 'secular humanism' and that, as the member of no 'faith community,' my aim is to produce an atheistically relativist account of the religious history of this period" (Lake, "Anti-Puritanism," 86n).

${ }^{45}$ Christopher Haigh, "The Recent Historiography of the English Reformation," in his English Reformation Revised, 19-21. 
ligious change in England, but a few of these have struck jarring or anachronistic notes-one thinks of Ethan Shagan's decision to make "collaboration"- a concept principally associated with totalitarian regimes of the twentieth century-central to his otherwise effective and enlightening study of the reception and appropriation of governmental religious policy at the parish level. ${ }^{46}$

What is particularly striking is that several of the paradigms informing histories of other national Reformations, or of European Reformation movements as a whole, have failed to appeal very much to historians of England. ${ }^{47} \mathrm{~A}$ case in point here is the confessionalization model, as originally developed by Heinz Schilling for German Protestant territories, and by Wolfgang Reinhard for the institutions and societies of Catholic Europe. This thesis argues that state authorities across Europe in the later sixteenth and seventeenth centuries consciously promoted a single, and increasingly clearly doctrinally defined, form of confessional Christianity within their territories as a central aspect of state formation and an instrument for the social disciplining of subjects. ${ }^{48}$ The confessionalization thesis has been endlessly debated and refined by scholars of the European reformations, but it has exercised very little leverage one way or the other on discussions of the Reformation in England. ${ }^{49}$ Arguably, England does not fit very comfortably inside any version of the confessionalization model - it remained from an early stage too stubbornly pluralistic, and the formularies the English Church produced and adopted for itself never really amounted to a proper confession around which a state-building agenda could easily be organized. But the case has not been argued out. Schilling himself locates the beginnings of Anglican confessionalization in the Edwardian Book of Common Prayer and Thirty-Nine Articles of 1563. But, so far as I know, no English-speaking scholar has taken serious issue with him for saying so. ${ }^{50} \mathrm{We}$ can

\footnotetext{
${ }^{46}$ Shagan, Popular Politics, 13-17, 257-69, 291, 295, 299.

${ }^{47}$ A point also made by Andrew Pettegree, “A. G. Dickens and His Critics: A New Narrative of the English Reformation," Historical Research 77, no. 195 (February 2004): 44. An interesting exception is the work of my colleague Beat Kümin, The Shaping of a Community: The Rise and Reformation of the English Parish c.1400-1560 (Aldershot, 1996), which applies the Swiss historian Peter Blickle's concepts of "communalism" and "communal Reformation" to developments at the parish level in England. See Blickle, Gemeindereformation: Die Menschen des 16; Jahrhunderts auf dem Weg zum Heil (Munich, 1985), and "Communal Reformation and Peasant Piety: The Peasant Reformation and Its Late Medieval Origins," Central European History 20, nos. 3-4 (September 1987): 216-28. Kümin sees a local communalizing impulse as thwarted by the Reformation in England (Shaping of a Community, 260-64).

${ }^{48}$ Heinz Schilling, Konfessionskonflict und Staatsbildung (Gütersloh, 1981), Religion, Political Culture and the Emergence of Early Modern Society (Leiden, 1992), and "Confessional Europe," in Handbook of European History, 1400-1600, ed. Thomas A. Brady, Heiko O. Oberman, and James D. Tracy, 2 vols. (Leiden, 1995), 2:641-70; Wolfgang Reinhard, "Reformation, Counter-Reformation and the Early Modern State: A Reassessment," Catholic Historical Review 75, no. 3 (July 1989): 385-403; Reinhard and Schilling, eds., Die Katholische Konfessionalisieung (Gütersloh, 1995); John M. Headley, Hans J. Hillerbrand, and Anthony J. Papadas, eds., Confessionalization in Europe, 1555-1700 (Aldershot, 2004).

${ }^{49}$ The exceptions are an interesting short discussion by the literary critic Thomas Betteridge, Literature and Politics in the English Reformation (Manchester, 2004), 1-4, and a quirky essay by Peter I. Kaufman, "Reconstructing the Context for Confessionalization in Late Tudor England: Perceptions of Reception, Then and Now," in Headley et al., Confessionalization in Europe, 275-87. See also the recent, though qualified, contention of Patrick Collinson that "Elizabethan England was a confessional state" ("The Politics of Religion and the Religion of Politics in Elizabethan England," Historical Research 82, no. 215 [2009]: 74-92).

${ }^{50}$ Schilling, "Confessional Europe," 641.
} 
note a similar reticence with respect to the provocative Christianization and acculturation theses associated with Jean Delumeau and Robert Muchembled. ${ }^{51}$ These historians regard Reformation, in both its Protestant and Catholic variants, as an attempt by social elites to control and reform the culture and customs of the rural masses, turning them from superstitious semipagans into "real" (and obedient) Christians. The paradigm has failed to strike much of a chord with historians of the English Reformation, although there are some parallels with the work of social historians examining the local impact of a putative Puritan "reformation of manners" in local communities. ${ }^{52}$

Another familiar concept from the wider European historiography-that of the so-called Second Reformation-has also failed to take root in the English setting. This label refers to the pattern whereby, particularly in Germany from the second half of the sixteenth century, a Reformed or Calvinist form of Protestant polity attempted to displace an established Lutheran one. The term also carries wider connotations of a second wave of moral and doctrinal transformation, an attempt to "reform the Reformation." ${ }^{53}$ In its strictly doctrinal sense, it is easy to see why the concept might be of limited applicability to the English scene. In terms of dominant theological influences, England was wedded to its second Reformation before it had hardly flirted with, let alone embraced, its first. Alec Ryrie dates what he calls the "strange death of Lutheran England" to the latter part of Henry VIII's reign, and a Reformed, later more explicitly Calvinist, doctrinal emphasis was a leitmotif of English Protestantism from the late 1540s onward. ${ }^{54}$ The concept of a second English Reformation has, however, had at least one significant outing. In his Stenton lecture of 1986, entitled "From Iconoclasm to Iconophobia," Patrick Collinson identified in the years around 1580 an abrupt cultural caesuraa moment when the opinion formers of English Protestantism turned their backs on a wide variety of visual, dramatic, and musical forms they, or rather their predecessors, had happily employed in the past ${ }^{55}$ Recent postrevisionist scholarship on the continuing place of the visual in late Elizabethan and early Stuart religious culture, some of it produced by Collinson's own students, have persuaded him that he overstated the case. ${ }^{56}$ Yet a willingness to think in terms of primary and secondary, or even tertiary, stages and phases of Reformation in England is surely

\footnotetext{
${ }^{51}$ Jean Delumeau, Catholicism between Luther and Voltaire: A New View of the Counter-Reformation, trans. Jeremy Moiser (London, 1977); Robert Muchembled, Popular Culture and Elite Culture in France, 1400-1700, trans. Lydia Cochrane (Baton Rouge, LA, 1985), "Lay Judges and the Acculturation of the Masses (France and Southern Low Countries, Sixteenth to Eighteenth Centuries)," trans. John Burke, in Religion and Society in Early Modern Europe, 1500-1800, ed. Kaspar von Greyerz (London, 1984), 56-65.

${ }^{52}$ Keith Wrightson and David Levine, Poverty and Piety in an English Village: Terling, 1525-1700, 2nd ed. (Oxford, 1995).

${ }^{53}$ Bodo Nischan, Prince, People, and Confession: The Second Reformation in Brandenburg (Philadelphia, 1994); Harm Klueting, "Problems of the Term and Concept 'Second Reformation': Memories of a 1980s Debate," in Headley et al., Confessionalization in Europe, 37-49.

${ }^{54}$ Alec Ryrie, "The Strange Death of Lutheran England," Journal of Ecclesiastical History 53, no. 1 (January 2002): 64-92.

${ }^{55}$ Patrick Collinson, "From Iconoclam to Iconophobia: The Cultural Impact of the Second English Reformation," in The Impact of the English Reformation, 1500-1640, ed. Peter Marshall (London, 1997), 278-308.

${ }^{56}$ Watt, Cheap Print, 134-40; Walsham, Providence, 250-66.
} 
a basic and essential way of making sense out of the process and represents an effective challenge to Haigh's view that the progression of reform was simply one damn thing after another. ${ }^{57}$

There is, however, one thematic paradigm, developed for the study of the German Reformation, that has been imported wholesale into the English setting: Gerald Strauss's controversial thesis on Lutheran pedagogy, developed in the mid1970s in his book Luther's House of Learning and in a widely debated article, "Success and Failure in the German Reformation." 58 Strauss argued that the evidence of local visitations produced by the officials of the Lutheran Church itself demonstrates that in places like Brandenburg and Electoral Saxony, the Reformation was an educational failure, making little meaningful impact on the religious and cultural attitudes of the populace, especially the young. Christopher Haigh has directly invoked Strauss's categories in a slew of recent publications, most directly in a 2001 article, "Success and Failure in the English Reformation" (note the definite article). Like Strauss, Haigh is interested in the effectiveness of Protestant catechizing and largely unimpressed by what he finds. From the evidence of visitation reports, and the stated grounds for excluding parishioners from communion, Haigh concludes that, eventually, after about 1600, English people did learn their catechism. But the great majority had not progressed beyond a rote learning of commandments and creed, let alone seriously internalizing Protestant doctrine. ${ }^{59}$ One is tempted to observe here that "success and failure" seems less an attempt to engage comparatively with debates on the historiography of Reformation Germany than a concept chosen for the facility with which it could be mapped onto a preexisting set of revisionist presumptions and concerns. Nonetheless, Haigh's recent work reflects a discernible trend in English Reformation studies, a shift from a primarily doctrinal to a more pastoral investigation of how Protestantism was purveyed and purchased in the localities. ${ }^{60}$

The apparent reluctance of much of the historiography of the English Reformation to align itself with the issues and debates of the wider European world has both a context and a history. It is, in large measure, the product of a longstanding perception, nurtured in England itself but shared, one suspects, quite

\footnotetext{
${ }^{57}$ Professor Anthony Milton of Sheffield University is currently working on a major project entitled "England's Second Reformation," a phrase he is applying to the reshaping of the Church of England's identity between 1636 and 1666 .

${ }^{58}$ Gerald Strauss, "Success and Failure in the German Reformation," Past and Present, no. 67 (May 1975): 30-63, Luther's House of Learning: Indoctrination of the Young in the German Reformation (Baltimore, 1978).

${ }^{59}$ Christopher Haigh, "Success and Failure in the English Reformation," Past and Present, no. 173 (November 2001): 28-49, "Communion and Community: Exclusion from Communion in Post-Reformation England," Journal of Ecclesiastical History 51, no. 4 (October 2000): 721-40, "The Taming of Reformation: Preachers, Pastors and Parishioners in Elizabethan and Early Stuart England," History 85, no. 280 (October 2000): 572-88, and The Plain Man's Pathways to Heaven: Kinds of Christianity in Post-Reformation England (Oxford, 2007), esp. chap. 3.

${ }^{60}$ See Patrick Collinson, "Shepherds, Sheepdogs, and Hirelings: The Pastoral Ministry in Post-Reformation England," in The Ministry: Clerical and Lay, ed. W. J. Sheils and Diana Wood (Cambridge, 1989), 185-220; Kenneth Fincham, Prelate as Pastor: The Episcopate of James I (Oxford, 1990); Eric J. Carlson, "The Boring of the Ear: Shaping the Pastoral Vision of Preaching in England, 1540-1640," in Preachers and People in the Reformations and Early Modern Period, ed. Larissa Taylor (Leiden, 2001), 221-48, "Good Pastors or Careless Shepherds? Parish Ministers and the English Reformation," History 88, no. 291 (July 2003): 423-36.
} 
widely across the Anglophone world, that English history is fundamentally different from that of a defining "other," a separate imagined place, usually referred to as "the continent." The habit of making an almost Manichean contrast between Britain and "the continent" remains endemic in British cultural and political life, although academic historians, British and American alike, ought to know better. MacCulloch in particular has commented on the "element of imperial nostalgia" implicit in this usage, as well as on the bizarre incongruity whereby Great Britain and Ireland do not form part of the continent, yet other islands, such as Corsica or Malta, undoubtedly do. ${ }^{61}$ Yet a notion of English exceptionalism, or at least of a very marked English particularism, has proved surprisingly durable in Reformation studies. It is, for example, right at the heart of Christopher Haigh's conception of "English Reformations." That book was not titled "The Reformation in England," so he tells us, because that would imply that what happened here was "simply a local manifestation of the wider European movement, an integral part of 'the Reformation." Haigh does not, of course, deny all connections with what was happening elsewhere, but he is insistent that his subject is not something "exported across the Channel and installed in England by Luther, Calvin and Co. Ltd." 62

This literally insular conception of the English Reformation has come under sustained and effective attack in recent years. Reforming movements and moments in England did not merely, as Haigh puts it, "take some ideas from the Reformation"; they imported wholesale: personnel, ideology, and important bonds of solidarity linked England to other parts of Europe throughout the sixteenth century and into the seventeenth. In part, this dependency reflects a curious feature of the Reformation in England in the sixteenth century, its failure to produce any truly original systematic theologian of international standing. The individual with arguably the greatest potential to become so, John Frith, was burned at the age of 30, right at the outset of the process in 1533. Thereafter, English Protestantism's theological bearings were taken from abroad. Our understanding of a Calvinist consensus - or perhaps it is better described, following Peter Lake, as a Calvinist hegemony-in the Elizabethan Church has been supplemented in recent years by a growing awareness of how much the emergent shape and theology of the English Protestant Reformation owed to contacts with Zurich and to the figure of Heinrich Bullinger - a case that has been strongly argued by MacCulloch, Carrie Euler, Torrance Kirby, and others. ${ }^{63}$ More generally, there is little doubt that the great majority of English churchmen, up to and beyond 1600, considered themselves part of a larger whole-an international brotherhood of true Christians united in opposition to the machinations of the papal Antichrist. For many among the early Elizabethan clergy it was axiomatic that the Church of England should seek to conform itself to the pattern of the best Reformed European Churches. Writing to Bullinger in 1566, the Oxford dons Lawrence Humphrey and Thomas Sampson asked rhetorically, "Why should we look for precedents from our enemies the

\footnotetext{
${ }^{61}$ MacCulloch, "Protestantism in Mainland Europe," 699, "Putting the English Reformation on the Map," Transactions of the Royal Historical Society, 6th ser., 15 (2005): 76.

${ }^{62}$ Haigh, English Reformations, 12-13.

${ }^{63}$ Lake, "Puritanism, Arminianism and Nicholas Tyacke," 10; Diarmaid MacCulloch, Tudor Church Militant: Edward VI and the Protestant Reformation [published in the United States as The Boy King] (London, 1999), 167-74; Carrie Euler, Couriers of the Gospel: England and Zurich, 1531-1558 (Zurich, 2006); W. J. Torrance Kirby, The Zurich Connection and Tudor Political Theology (Leiden, 2007).
} 
papists, and not from you, our brethren of the reformation?" ${ }^{64}$ There is a revealing glimpse of a pervasive mind-set in the passing reference of Bishop John Jewel to the time "when we burnt Servetus" (the antitrinitarian thinker executed in Geneva in 1553). ${ }^{65}$ The English Church, in other words, was not just some eccentric nextdoor neighbor, but a full and acknowledged sibling in the family of European Reformed churches.

The notion of a peculiarly English Sonderweg in the Reformation era is easy enough to criticize, but it is not simply the result of historical chauvinism, compounded on both sides of the Atlantic by a long-standing lack of facility in modern European languages. We can, and should, make the point that all national Reformations were distinct and different and that all were, to a greater or lesser degree, interconnected with Reformation movements elsewhere. Yet, having said that, the undoubted fact remains that England has been the birthplace of a unique and distinctive strand of world Christianity-something called Anglicanism or Episcopalianism-and that the birth, or at least the conception, of that "-ism" must surely have taken place at some point within the Reformation period itself. Use of the word "Anglican," still less "Anglicanism," has of late become something of an unforgiveable faux pas in English Reformation studies. In light of what has just been said about an internationally minded English Protestant identity, it is of course potentially very misleading, and it is also, strictly, an anachronism. The Oxford English Dictionary gives its earliest citation of "Anglican" from 1635, but the word was not in widespread currency in England until the nineteenth century. ${ }^{66}$ Undoubtedly, in the past, and until it was dealt twin death blows by Norman Jones and Winthrop Hudson in the early 1980s, the identification of the Elizabethan Settlement of 1559 as an Anglican via media was, consciously or unconsciously, made to serve ideological ends. ${ }^{67}$ It framed a narrative of Elizabethan "Anglican" bishops holding at bay an oppositional and decidedly un-English Puritan movement, and it provided a properly attested birth certificate for the Church of England, particularly in its AngloCatholic incarnation. Continuity with the past, an eschewing of doctrinal and anticeremonial extremism, and a suspicion of foreign influence and innovation all could be made part of the pedigree. This is what MacCulloch has called the "myth of the English Reformation"-the myth that it did not really happen. ${ }^{68}$

MacCulloch is surely right to bang the drum loudly about this, but Anglicanism, or its evolutionary ancestor, did come from somewhere. And as the English Ref-

\footnotetext{
${ }^{64}$ Eamon Duffy, "The Shock of Change," in Platten, Anglicanism and the Western Christian Tradition, 49.

${ }^{65}$ Peter Lake, "The 'Anglican Moment'? Richard Hooker and the Ideological Watershed of the 1590s," in Platten, Anglicanism and the Western Christian Tradition, 92.

${ }^{66}$ Diarmaid MacCulloch, "The Latitude of the Church of England," in Fincham and Lake, Religious Politics in Post-Reformation England, 41-42. See, however, the polemical use of the cognate "Anglianisme" to describe the religious polity of England by the Catholic Thomas Harrab, Tessaradelphus, or The four brothers (Lancashire, 1616), A2r-v, E2v ff. (a reference I owe to Alec Ryrie).

${ }^{67}$ Norman Jones, Faith by Statute: Parliament and the Settlement of Religion, 1559 (London, 1982); Winthrop S. Hudson, The Cambridge Connection and the Elizabethan Settlement of 1559 (Durham, NC, 1980). These studies have demonstrated that Elizabeth and her advisors were aiming in 1559 at an unambiguously Protestant settlement, the main opposition to which came not from Puritans but from Catholic resistance in the House of Lords.

${ }^{68}$ Diarmaid MacCulloch, "The Myth of the English Reformation," Journal of British Studies 30, no. l (January 1991): 1-19.
} 
ormation, or reformations, has crept forward in time, Reformation historians can no longer get away with saying "not our problem" in relation to this question of origins. The form of churchmanship that provided the dominant ethos for the Church of England after 1660-non-Calvinist and based firmly on a prescriptive liturgy, with due allowance for ceremony and sacrament-was certainly around before the civil wars. In fact, its unexpected political dominance in the 1630sin the form of Laudianism or English Arminianism - is widely credited as being a major factor in the outbreak of those wars. One of the dangers of the "Calvinist Consensus" thesis in some of its less nuanced versions is that it makes Laudianism into a kind of deus ex machina, emerging from nowhere to devastate the settled ecosystem of so-called Jacobethan Protestantism. That model has largely, though not entirely, ceased to command conviction. Some of the most interesting work in English Reformation studies of late has been precisely concerned with probing the fractures and fault lines of the Calvinist Church of England in the later Elizabethan years. There has been a renewed interest in Richard Hooker, a theologian perhaps better seen not as the apotheosis of Anglicanism but, in Peter Lake's provocative formula, as its "inventor." ${ }^{69}$ And we have started to look again at other incongruous figures like Lancelot Andrewes-those whom historians have dubbed, in a somewhat bizarre but nonetheless useful phrase, avant-garde conformists, the harbingers of a style of theology and devotion that was to reach full flower during the ascendancy of Archbishop Laud. ${ }^{70}$

Such investigations need not be-indeed, clearly have not been-the "ancestor worship" against which MacCulloch warns us. Instead, an alertness to the embryonic presence of later ecclesiastical and theological developments is an obvious way of maintaining the coherence of the Reformation as an object of study and of promoting dialogue between those working on its secondary and tertiary phases. At the same time, this can help us to recognize that the Protestant Reformation in England was not so much a straightforward unitary project that either succeeded or failed, but a deeply ambivalent and unstable construct from its very inception. The roots of Laudianism-Anglicanism can be traced not just to theological innovations of the 1590s but to profound ambiguities within the Elizabethan settlement of 1559 over such matters as the placing of altars in churches. ${ }^{71}$ An eventual characteristic of Anglicanism-its acknowledgment or even celebration of continuity with the medieval Christian past—surely also has mid-Tudor roots. For all its avowal of a distinctly reformed doctrine of grace, the Elizabethan Church was decidedly unusual among the Protestant churches of Europe in retaining wholesale some key aspects of its medieval Catholic predecessor-its structure of church courts and canon law, its episcopal system, and its cathedrals, with their full complements of clergy and rich liturgical and musical life. All of these were resources

\footnotetext{
${ }^{69}$ Peter Lake, Anglicans and Puritans? Presbyterianism and English Conformist Thought from Whitgift to Hooker (London, 1988), 227-28.

${ }^{70}$ Peter Lake, "Lancelot Andrewes, John Buckeridge, and Avant-garde Conformity at the Court of James I," in The Mental World of the Jacobean Court, ed. Linda Levy Peck (Cambridge, 1991), 113-33; Peter McCullough, ed., Lancelot Andrewes: Selected Sermons and Lectures (Oxford, 2005), and a forthcoming biography.

${ }^{71}$ Kenneth Fincham and Nicholas Tyacke, Altars Restored: The Changing Face of English Religious Worship, 1547-c.1700 (Oxford, 2007).
} 
out of which an alternative Protestant vision could be fashioned..$^{72}$ The corpse of English exceptionalism will not entirely stay quiet in its grave.

All of this is bringing me, not before time, to the final section of this essay and my promise to provide some prescriptions for the future health of the subdiscipline of English Reformation studies. The mission statement here might commit us to upholding the cohesion of the Reformation as a subject and to seeking to ask interesting questions about it beyond the rather tired above/below, fast/slow, success/failure paradigms. In order to help us do so, we should recognize a couple of important qualifications to the picture that has been painted thus far, and (to return to the metaphor that opened this essay) we should search for those corners of the garden that now look ready for planting and where new shoots are already starting to appear.

In the first place, it would be unfortunate to give the impression that the important new frontiers of English Reformation history are all, or ought to be, at the chronologically later end of the process. Normally, historians are fixated, almost unhealthily fixated, on issues of causation. Yet the origins of and explanations for the transformations that began to affect English religious culture from the 1520s onward seem of late to have slipped down the order of priorities, and this is unfortunate. ${ }^{73}$ In part, no doubt, this is due to the sheer success of revisionist scholarship in torpedoing the older triumphalist Protestant and nationalist narratives of the early Reformation. The effect, for much of the 1990s, of Duffy's The Stripping of the Altars was not so much to initiate a debate over the character of late medieval Catholicism as to close it down. One issue that Duffy pointedly passed over in his account-the significance of the late medieval heresy of the Lollards-has continued to generate sparks. But the debate over the contribution of Lollardy to the English Reformation seems currently deadlocked. In a heroic act of self-abnegation, Richard Rex devoted a 2002 book on the subject to demonstrating that Lollardy was almost entirely insignificant. ${ }^{74}$ MacCulloch, by contrast, remains convinced that Lollard concerns-biblical legalism, intense hostility to religious imagery, skepticism about the real presence in the eucharist-imprinted themselves onto the central theological agendas of the Henrician and Edwardian Reformations, but he has not been able to demonstrate in any detail the processes by which this could have happened. ${ }^{75}$

The prevalence of heresy, anticlericalism, and dissent in pre-Reformation society remains a significant question for investigation. But an arguably more fruitful line of inquiry, for England as for elsewhere in Europe, leads into the orthodox religious culture of the late Middle Ages and its capacity for generating self-critiques and new devotional emphases. Interesting work of a broadly postrevisionist character is now starting to happen here. Studies by scholars such as Susan Wabuda, Christine

\footnotetext{
${ }^{72}$ Julia Merritt, "The Cradle of Laudianism? Westminster Abbey, 1558-1630," Journal of Ecclesiastical History 52, no. 4 (October 2001): 623-46; MacCulloch, Tudor Church Militant, 210-13.

${ }^{73}$ Significant exceptions here include Shagan, Popular Politics; and George Bernard, The King's Reformation: Henry VIII and the Remaking of the English Church (New Haven, CT, 2005).

${ }^{74}$ Richard Rex, The Lollards (Basingstoke, 2002).

${ }^{75}$ MacCulloch, "Putting the English Reformation on the Map," 80-81. Some of the most suggestive recent research in this field emphasizes the extent to which the boundaries between orthodoxy and heresy were malleable and permeable (Shannon McSheffrey, "Heresy, Orthodoxy, and English Vernacular Religion, 1480-1525," Past and Present, no. 186 [February 2005]: 47-80).
} 
Peters, and Rob Lutton allow us to see that the appeal of evangelicalism to its first generation of converts can to a significant extent be considered a reflection of the success of the late medieval Church in inculcating an intensely Christocentric spirituality. ${ }^{76}$ No doubt, as the interpretative wheel starts to turn, the currently dominant revisionist picture of widespread satisfaction with and popular support for the institutions and rituals of the late medieval Church will come under ever closer critical scrutiny. But closer attention to the earliest phases of reform, and to what Alec Ryrie and I have called "the beginnings of English Protestantism," need not be in any way celebratory or represent a neo-Protestant counterattack against the occupying forces of Catholic revisionism. ${ }^{77}$ For further evidence of that, one need look no further than the Harvard literary scholar James Simpson's recent book, Burning to Read - a powerfully polemical study of Tyndale and his circle, which locates the roots of modern illiberalism and fundamentalism in Lutheran doctrines of justification and the reading practices evangelicals formulated for vernacular scripture. ${ }^{78}$

A second unsatisfactory feature of the landscape I have been sketching so far is that it has been focused squarely on the history of the Church of England and its adherents. Here we do need to recognize that a potential danger with the concept of "the Reformation," as opposed to plural reformations, is an implicit unidirectionalism that follows the history of an institution and sees Anglicanism as the telos of the English Reformation, whereas in fact it was only one of a number of possible, and actual, outcomes. The origins of Protestant nonconformity, like the origins of Anglicanism, require tracing and tracking back into the sixteenth century. ${ }^{79}$ We also need studies of the movements and ideas that eventually turned out to be historical or theological dead-ends, such as Tom Freeman's portrait of the mid-Tudor "Freewillers" and David Como's painstaking reconstruction of Puritan antinomianism in the pre-Civil War period. ${ }^{80}$

Still more pressing is the need to integrate Catholics and Catholicism more firmly into mainstream narratives of the English Reformation. ${ }^{81}$ In this context, the reign of Mary represents a major challenge and an obvious problem for any implicitly unidirectional account. It also remains a major historiographical battlefield. Duffy's decidedly upbeat chapter on Marian Catholicism was perhaps the

\footnotetext{
${ }^{76}$ Susan Wabuda, Preaching during the English Reformation (Cambridge, 2002); Christine Peters, Patterns of Piety: Women, Gender and Religion in Late Medieval and Reformation England (Cambridge, 2003); Robert Lutton, Lollardy and Orthodox Religion in Pre-Reformation England: Reconstructing Piety (London, 2006).

${ }^{77}$ Peter Marshall and Alec Ryrie, eds., The Beginnings of English Protestantism (Cambridge, 2002).

${ }^{78}$ James Simpson, Burning to Read: English Fundamentalism and Its Reformation Opponents (Cambridge, MA, 2007).

${ }^{79}$ The best starting point here is Jacqueline Eales, "A Road to Revolution: The Continuity of Puritanism, 1559-1642," in The Culture of English Puritanism, 1560-1700, ed. Christopher Durston and Jacqueline Eales (Basingstoke, 1996), 184-209.

${ }^{80}$ Thomas S. Freeman, "Dissenters from a Dissenting Church: The Challenge of the Freewillers, 1550-1558," in Marshall and Ryrie, Beginnings of English Protestantism; David Como, Blown by the Spirit: Puritanism and the Emergence of an Antinomian Underground in Pre-Civil-War England (Stanford, CA, 2004).

${ }^{81}$ An important lead here has been given by the researches of Michael Questier. See his Conversion, Politics, and Religion in England, 1580-1625 (Cambridge, 1996), and Catholicism and Community in Early Modern England: Politics, Aristocratic Patronage and Religion, c.1550-1640 (Cambridge, 2006).
} 
most contentious part of The Stripping of the Altars, and it set the tone for equally optimistic assessments of the achievements and potential of Marian Catholicism by scholars such as Tom Mayer, Lucy Wooding, and Bill Wizeman. ${ }^{82}$ It was also much criticized in some quarters for effectively ignoring the feature most associated with the religious history of the reign: the campaign of religious persecution that led to the burning of around 300 Protestant men and women between 1555 and 1558. That criticism struck home, and Duffy made the burnings one of the central themes of his Birkbeck lectures on "Religion under Mary Tudor," delivered in Cambridge (United Kingdom) in the latter part of 2007 and now published in book form. His thesis that the policy was both inevitable and to a considerable extent successful is likely to be highly controversial. ${ }^{83}$

Whether the burnings were working or not, they came to an end with Mary's death in November 1558. Revisionist historians of Catholic restoration in Mary's reign are sometimes criticized for giving too much prominence to whimsical "whatifs" and "might-have-beens." The Marian Counter-Reformation failed. Its main, albeit unintended, achievement was to consolidate the forces of reform and to lay the basis for a lasting anti-Catholic myth of Protestant national identity. But in one very important way, the achievement of Mary's reign was far from counterfactual: it ensured the subsequent survival of Catholicism in England and thereby enshrined religious division and plurality as a permanent feature of English political and cultural life. This is a bald and bold claim, which runs counter to John Bossy's seductive and polished thesis that English Catholicism had been effectively extirpated by circa 1570 and was rebuilt from scratch by Jesuit and other missioners in the second half of Elizabeth's reign. ${ }^{84}$ But I think the claim has merit and deserves further investigation. The thorough re-Catholicization between 1553 and 1558 , both of the upper reaches of the ecclesiastical hierarchy and of the universities, led to a flood of highly educated clerical exiles to Louvain and other centers. Elizabethan Catholic exile, it should be recognized, was a much larger and more politically formidable phenomenon than Marian Protestant exile. ${ }^{85}$ At home, the difficulty experienced by early Elizabethan bishops-a difficulty apparently greater than that faced by any of their Tudor predecessors-in getting parishes to obey official mandates about the ordering of churches, and the removal or destruction of forbidden cultic objects, argues for a greater sense of clarity on the part of ordinary English people about the religious issues at stake than had been seen in the $1530 \mathrm{~s}$ and $1540 \mathrm{~s} .{ }^{86}$

This leads me to my final point and to a tentative (re)definition of what was most significant about "the English Reformation" and of what invests it with a conceptually holistic character beyond the merely contingent and temporal. My proposal here is that we should see the English Reformation primarily as a crucible

\footnotetext{
${ }^{82}$ Thomas F. Mayer, Reginald Pole: Prince and Prophet (Cambridge, 2000), chaps. 6-8; Lucy E. C. Wooding, Rethinking Catholicism in Reformation England (Oxford, 2000); William J. Wizeman, The Theology and Spirituality of Mary Tudor's Church (Aldershot, 2006).

${ }^{83}$ Eamon Duffy, Fires of Faith: Catholic England under Mary Tudor (New Haven, CT, 2009).

${ }^{84}$ John Bossy, The English Catholic Community, 1570-1850 (London, 1975).

${ }^{85}$ Peter Marshall, "Religious Exiles and the Tudor State," in Discipline and Diversity, ed. Kate Cooper and Jeremy Gregory (Suffolk, 2007), 263-84.

${ }^{86}$ A phenomenon noted by Ronald Hutton, "The Local Impact of the Tudor Reformations," in Haigh, English Reformation Revised, 134-35.
} 
of religious identity formation-as the period, and the process, through which something akin to modern religious and denominational identities came into existence. Or perhaps it is more accurate to say that something akin to the modern concept of a religious identity was an inevitable medium- and long-term consequence of the shattering of late medieval England's socially integrative religious culture in the first half of the sixteenth century. ${ }^{87}$ Such an approach is necessarily pluralistic, and to avoid accusations of ancestor worship, it must naturally examine why some religious identities did not survive and cohere through to the end of the period. Yet it should encourage us to build upon the often valuable work of earlier denominational historians rather than to dismiss their efforts with a postconfessional sneer.

It is tempting to describe the English Reformation I am talking about here as a process of confessionalization, although, as already noted, this is a word and a concept we need to handle with some care. Confessionalization usually denotes a largely top-down process. The institutions of church and state combine to articulate the lineaments of a single national faith and to mold an obedient and conformable laity through processes of social discipline. Popular confessionalization - that sense of conscious confessional identity on the part of individuals and communities that allowed them to "own the religious labels"-gradually follows upon state confessionalization. ${ }^{88}$

But the English pattern seems somewhat different from this: a fair amount of popular confessionalization preceded, accompanied, and sometimes opposed fitful attempts at state confessionalization. ${ }^{89}$ Of course, England was not unique in this respect: French and Dutch Calvinism, for example, developed in disobedience to state authority, and a strong emphasis on bottom-up confessionalization characterizes some recent work on anabaptism. ${ }^{90}$ Yet across the period as a whole, the English state appears particularly inept at monopolizing and directing the process, and that fundamentally political factor may be a, or even the, crucial determinant of why things worked out the way they did in the formation of English religious cultures. It was not for want of trying. Thanks to the unique theological-political innovation of the English Reformation-the Royal Supremacy over the Churchreligious changes in England were more overtly Erastian than almost anywhere else in Europe. At the same time, successive Tudor and Stuart governments worked hard to establish and maintain an intrinsic connection between religious deviance and political dissidence. ${ }^{91}$ Yet somehow the outcome was not the ordered comprehension of society within a unitary confessional Church, on the model eventually established in, say, Lutheran Sweden. An explanation for this must start with Henry VIII, who used his Royal Supremacy to create a hybrid theology and polity in which probably no one but he actually believed: in the final years of his reign,

\footnotetext{
${ }^{87}$ Still immensely valuable here is John Bossy's perception that the primary religious transformation in Europe in the early modern era was the process by which Christianity came to signify a body of beliefs rather than a body of people (Christianity in the West [Oxford, 1985], esp. 171).

${ }^{88}$ The phrase is Diarmaid MacCulloch's (Reformation, 338).

${ }^{89}$ An argument developed in my Religious Identities in Henry VIII's England (Aldershot, 2006).

${ }^{90}$ Michael Driedger, Obedient Heretics: Mennonite Identities in Lutheran Hamburg and Altona during the Confessional Age (Aldershot, 2002).

${ }^{91}$ For incisive discussion of these developments, see Alexandra Walsham, Charitable Hatred: Tolerance and Intolerance in England, 1500-1700 (Manchester, 2006), chap. 2.
} 
his subjects, or significant numbers of them, were already starting to make their own confessional choices. The seesaw of policy under Edward and Mary simultaneously widened existing divisions and clarified contested issues. The long reign of Elizabeth ought to have provided an opportunity for a more orderly top-down confessionalization of the English people, and to some extent it did. But Elizabeth inherited a nation in which sharp religious difference was already entrenched, and her regime lacked both the coercive power and the unity of purpose to eliminate Catholicism or bring Protestant dissidents firmly to heel. ${ }^{92}$ By the time of her Stuart successors, the ability of any English government to impose complete religious uniformity looked fairly negligible. And here the British context, a theme neglected in this essay, starts to look vital again, for the Stuart monarchy managed the remarkable feat of producing (or failing to repress) a different dominant version of Christianity in each of its three kingdoms, the majority faith in each case having to live alongside significant minorities of the other two, and the religious volatility of any one kingdom periodically threatening to infect its neighbors. ${ }^{93}$

Popular confessionalization in Reformation-era England was no doubt a slow and messy process, during the course of which many people learned to live with contradictions and to mask or sublimate their deepest religious inclinations. We have learned to pay attention to evolutionary abnormalities and spiritual amphibians-the conformist puritan, the church papist. Even at the top of society there were anomalies-stray "Lutherans" like Bishops Richard Cheyney and Edmund Guest in the generally solidly Calvinist ranks of the Elizabethan episcopate, not to mention the great religious anomaly and enigma that was Elizabeth I herself. ${ }^{94}$ It is often suggested that the frequent shifts and turns of government religious policy in the sixteenth century must have confused and disoriented people, leaving them with little clear sense of whether they were supposed to be Protestants, Catholics, or some other type of Christian. Yet I think the possibility that it had precisely the opposite result needs to be investigated seriously-that the orders to remove or restore altars, images, and books had a profoundly catechizing effect, encouraging people to think about their meanings more intensely than they had done before. And as communities divided, the presence of "others"-heretics or papists-invariably sharpened in a dialectical way a self-awareness of religious belonging. Martyrdom, and stories about martyrs, had the same effect. ${ }^{95}$ I think we

\footnotetext{
${ }^{92}$ As Patrick Collinson has acutely noted, this lack of strict religious uniformity, "far from making religion apolitical, as it might be in a liberal society, or in a secularized society indifferent to religion, made it the hottest of all political potatoes" ("Politics of Religion," 24).

${ }^{93}$ For a concise statement of this case, see Conrad Russell, The Causes of the English Civil War (Oxford, 1990), chap. 5 .

${ }^{94}$ Caroline Litzenberger, "Richard Cheyney, Bishop of Gloucester, an Infidel in Religion?" Sixteenth Century Journal 25, no. 3 (Fall 1994): 567-84; Fincham and Tyacke, Altars Restored, 78-79; Patrick Collinson, "Windows into a Woman's Soul: Questions about the Religion of Queen Elizabeth I," in his Elizabethan Essays (London, 1994), 87-118; Susan Doran, "Elizabeth I's Religion: The Evidence of Her Letters," Journal of Ecclesiastical History 51, no. 4 (October 2000): 699-720.

${ }^{95}$ Anne Dillon, The Construction of Martyrdom in the English Catholic Community, 1558-1603 (Aldershot, 2002); John N. King, Foxe's Book of Martyrs and Early Modern Print Culture (Cambridge, 2006); Thomas S. Freeman and Thomas F. Mayer, eds., Martyrs and Martyrdom in England, c.1400-1700 (Woodbridge, 2007). For the role pluralism could play in reinforcing religious difference, see Walsham, Charitable Hatred; Benjamin J. Kaplan, Divided by Faith: Religious Conflict and the Practice of Toleration in Early Modern Europe (Cambridge, MA, 2007).
} 
have probably heard too much about compliance, conformity, and passivity as the keynotes of English religion in the Reformation era. Or of the suggestion that none of it really mattered very much, except to a handful of zealots. Christopher Haigh concludes his English Reformations by noting that "parish congregations went to church: they prayed again to their God, learned again how to be good, and went off home once more. That was how it had been in 1530; that was how it was in 1590." 96

But English parishioners were not simply passive and stoic consumers of the officially prescribed diet. We know of parishes in Edwardian London removing their altars before they were required to by law, and of numerous parishes across the country celebrating the Latin mass again at the start of Mary's reign, even when it was still technically illegal so to do. ${ }^{97}$ In a later generation there was considerable popular and parochial resistance to Laudianism and, subsequently, considerable episcopalian resistance to the religious directives of the commonwealth. ${ }^{98}$ Of course, religious identity formation is a fluid and ongoing process, not confined to the century and a half between the early sixteenth century and the later seventeenth. But this era surely stands out as a period of intensity in religious and cultural change unprecedented since the conversion of England and (arguably) not replicated since. Contemporaries themselves understood this. They rejoiced that they had lived to see the triumph of the Gospel, or they mourned the overthrow of time-honored Catholic piety and neighborliness. ${ }^{99}$ Any convincing attempt to redefine the English Reformation, in other words, needs to start and end with the story of how English Christians managed to redefine themselves.

${ }^{96}$ Haigh, English Reformations, 295. An emphasis on essential continuities also characterizes the conclusion of Christopher Marsh, Popular Religion in Sixteenth-Century England (Basingstoke, 1998), 217-19.

${ }^{97}$ Fincham and Tyacke, Altars Restored, 15-17; Marshall, Reformation England, 89.

${ }^{98}$ David Cressy, England on Edge: Crisis and Revolution, 1640-1642 (Oxford, 2006); John Morrill, "The Church in England, 1642-9," in his Reactions to the English Civil War (Basingstoke, 1982), 89-114; Judith Maltby, "Suffering and Surviving: The Civil Wars, the Commonwealth and the Formation of 'Anglicanism," in Religion in Revolutionary England, ed. Christopher Durston and Judith Maltby (Manchester, 2006), 158-80.

${ }^{99}$ On the theme of Catholic nostalgia, see Eamon Duffy, "Bare Ruined Choirs: Remembering Catholicism in Shakespeare's England," in Dutton et al., Theatre and Religion, 40-57. 